\title{
Seismic Microzonation: A Case Study
}

\author{
Ankit Gupta ${ }^{1}$ and Kapil Mittal ${ }^{2 *}$ \\ ${ }^{1}$ Punjab State Electricity Board, India \\ ${ }^{2}$ Gurukul Kangri University, India
}

Submission: July 05, 2017; Published: August 28, 2017

*Corresponding author: Kapil Mittal, Assistant Professor, FET, Gurukul Kangri University, Haridwar, Uttarakhand, India, Email: kapilmittal007@gmail.com

\begin{abstract}
"As seismologists gained more experience from earthquake records, it became obvious that the problem could not be reduced to single peak acceleration. In fact, a full frequency of vibrations occurs" quote by famous Charles Francis Richter, an American seismologist and the inventor of Richter scale for measuring the magnitude of earthquake, explains the theory behind earthquake monitoring. After effects of earthquake are disastrous and therefore what mankind can do is only to take precautionary measures. Before taking these measures first thing is to know the seismic zone in which a landscape falls. This process is called Microzonation. In this paper authors suggest Seismic Microzonation technique to find the proper information regarding an Indian town Chandigarh so that prophylactic actions can be put into place before the calamity happens. Seismic Microzonation can be considered as the preliminary phase of earthquake risk mitigation studies.
\end{abstract}

\section{Introduction}

\section{Seismic microzonation}

Seismic Microzonation is defined as the process of subdividing potential seismic or earthquake prone area into zones with respect to some geological and geophysical characteristics of the sites such as ground shaking, liquefaction susceptibility, landslide and rock fall hazard, so that seismic hazards at different locations within the area can be correctly identified Slob et al. [1], Tuladhar et al. [2]. Microzonation provides the basis for site-specific risk analysis, which can assist in the mitigation of earthquake damages. In most general terms, seismic Microzonation is the process of estimating the response of soil layers under earthquake excitations and thus the variation of earthquake characteristics on the ground surface Mohanty et al. [3].

\section{Microzonation maps}

Regional geology can have a large effect on the characteristics of ground motion. The site response of the ground motion may vary in different locations of the city according to the local geology. A seismic zonation map for a whole country may, therefore, be inadequate for detailed seismic hazard assessment of the cities. This necessitates the development of Microzonation maps for big cities for detailed seismic hazard analysis. Microzonation maps can serve as a basis for evaluating sitespecific risk analysis, which is essential for critical structures like nuclear power plants, subways, bridges, elevated highways, sky trains and dam sites Bour et al. [4].

\section{Liquefaction}

Soil liquefaction describes a phenomenon whereby a fully saturated soil substantially loses strength and stiffness in response to an applied stress, usually earthquake shaking or other sudden change in stress condition, causing it to behave like a liquid.

\section{History of liquefaction}

Liquefaction in soil is one of the major problems in Geotechnical Earthquake Engineering. This phenomenon has been observed after each and every earthquake, but was brought to the attention of engineers only after Niigata (1964) and Alaska (1964) Earthquake. Some Microzonation work has been done for Delhi (Rao), but no study has so far been undertaken to establish liquefaction possibilities at local levels in Chandigarh. It has been, therefore, felt necessary to undertake a study to develop a liquefaction potential hazard map of Chandigarh.

\section{How and where it occurs}

The phenomenon is most often observed in saturated, loose, sandy soils. This is because loose sand has a tendency to compress when a load is applied. If the loading is rapidly applied and large enough, or is repeated many times (e.g. earthquake 
shaking, storm wave loading) such that it does not flow out in time before the next cycle of load is applied, the water pressures may build to an extent where they exceed the contact stresses between the grains of soil that keep them in contact with each other. This loss of soil structure causes it to lose all of its strength (the ability to transfer shear stress) and it may be observed to flow like a liquid (hence 'liquefaction').

\section{Location}

Chandigarh is located near the foothills of the Shivalik range of the Himalayas in northwest India. It covers an area of approximately $44.5 \mathrm{sq} \mathrm{mi}$ or $114 \mathrm{~km}^{2}$ and shares its borders with the states of Haryana and Punjab. The exact cartographic coordinates of Chandigarh are $30.74^{\circ} \mathrm{N} 76.79^{\circ} \mathrm{E}$. It has an average elevation of 321 metres (1053ft).

\section{Method}

In the Microzonation study of Chandigarh, multi parametric approach, using inputs from geological, geotechnical, geophysical and seismological database, has been adopted. The City, located over a thick sequence of clay, silt, sand and pebble of the Older Alluvium, has been explored by bore holes each of $30 \mathrm{~m}$ depth, in which Standard Penetration Test has been carried out at different depth sections and soil samples drawn for geo-mechanical tests.

\section{Seed's Method}

Seed \& Idriss [1] proposed the following procedure for liquefaction analysis:

a. Establish the design earthquake, and obtain the peak ground acceleration AMAX. Also obtain number of significant cycles corresponding to the magnitude of earthquake.

b. Determine tav (Shear stress generated due to earthquake) at depth $\mathrm{h}$ below ground surface.

c. Determine the value of standard penetration resistance value $(\mathrm{N})$ at depth h below ground surface. Obtain corrected $\mathrm{N} 1$ value after applying overburden correction to $\mathrm{N}$.

d. Determine $(\tau \mathrm{h} / \sigma \mathrm{v})$ for the given magnitude of earthquake and N1 value obtained in step (c). Multiplying $(\tau \mathrm{h} / \sigma \mathrm{v})$ with effective stress at depth $\mathrm{h}$ below ground surface, one can obtain the value of shear stress th required for causing liquefaction where $\sigma \mathrm{v}$ is Effective overburden pressure.

e. At depth $\mathrm{h}$, liquefaction will occur if $\tau$ av $>$ th.

Thus, repeat these steps for calculating other liquefaction depths.

\section{Arc GIS Approach}

The points of boreholes were plotted on Google Earth. This $\mathrm{kml}$ format file was then converted into shape file using Global Mapper. In ArcGIS, values of Factor of safety for peak acceleration values such as $0.15 \mathrm{~g}$ and $0.2 \mathrm{~g}$ were entered in the attribute table of these points shape file. Then Raster Interpolation using IDW interpolation method was used to demonstrate Seismic Microzonation of Chandigarh. This helped in creating zones on the basis of their safety against liquefaction.

\section{Result and Conclusion}

Thorough application of the above described technique results in following findings:

a. There is probability of liquefaction in the northwestern, western, central and south-western parts of Chandigarh and parts of Mohali, including Sectors 15-17, 22-25, 32-39, etc. where the groundwater occurs at shallow depth, in case of strong seismic excitation.

b. The study helps in creating zones on the basis of their safety against liquefaction.

c. Seed's method helped in finding out liquefaction depths [5].

In this paper authors explain the Microzonation technique for finding different seismic zone. It certainly helps the administration and government to take the necessary measures before any calamity happens. More work on such technique is proposed in concerned area using classical techniques like fuzzy logic Mittal et al. [6], multiple attribute decision making MADM Mittal et al. [7], Six-sigma Kaushik et al. [8] etc.

\section{References}

1. Slob S, Hack R, Scarpas T (2002) A methodology for seismic microzonation using GIS and SHAKE-a case study from Armenia, Colombia. Proceedings of $9^{\text {th }}$ congress of the International Association for Engineering Geology and the Environment: Engineering geology for developing countries, pp. 2843-2852.

2. Tuladhar R, Yamazaki F, Warnitchai P (2004) Seismic microzonation of the greater Bangkok area using microtremor observations. \& structural dynamics 33(2): 211-225.

3. Mohanty W, Yanger MW, Sankar KN, Indrajit P (2007) First order seismic microzonation of Delhi, India using geographic information system (GIS). Natural Hazards 40(2): 245-260

4. Seed IBM, Fouissac D, Dominique P, Martin C (1998) On the use of microtremor recordings in seismic microzonation. Soil dynamics and earthquake.

5. Seed HB, driss IM (1971) Simplified procedure for evaluating soil liquefaction potential. Journal of Soil Mechanics \& Foundations Div 97(9): 1249-1273.

6. Mittal K, Puran CT, Dinesh K, Prabhakar K, Zude Z (2016) Application of Fuzzy TOPSIS MADM approach in ranking \& underlining the problems of plywood industry in India. Cogent Engineering 3: 1-11.

7. Mittal K, Tewari PC, Khanduja D (2017) Productivity improvement under manufacturing environment using Shainin system and fuzzy analytical hierarchy process: a case study. The International Journal of Advanced Manufacturing Technology 92(1): 407-421.

8. Kaushik P, Dahiya VK, Mittal K (2017) Statistics for industries: A sophisticated approach. Management Science Letters 7(8): 397-406. 
(i) This work is licensed under Creative Commons Attribution 4.0 License

DOI: 10.19080/CERJ.2017.01.555565
Your next submission with Juniper Publishers will reach you the below assets

- Quality Editorial service

- Swift Peer Review

- Reprints availability

- E-prints Service

- Manuscript Podcast for convenient understanding

- Global attainment for your research

- Manuscript accessibility in different formats ( Pdf, E-pub, Full Text, Audio)

- Unceasing customer service

Track the below URL for one-step submission https://juniperpublishers.com/online-submission.php 